\title{
BUSINESS SUCCESS ANALYSIS IN THE HOTEL INDUSTRY
}

\author{
Milovan Stanišić, \\ Nikica Radović, \\ Jelena Nikolić
}

Singidunum University, Belgrade, Serbia

\begin{abstract}
:
When analyzing a company's business operations, business indicators are considered, which, on the basis of the values obtained at the calculation stage, point to its financial position, i.e. its situation. In addition to standard business indicators, group models of indicators, also known as "prognostic models" are created and by their application it is possible to predict financial situation, i.e. stability or instability of a company. In this paper, the data from the financial statements for 2013, 2014, 2015 and 2016 will be tested using Kralicek's DF model and Quick Test and a forecast regarding business stability of the sampled hotels in Serbia will be provided.
\end{abstract}

Keywords:

hotel industry, business indicators, Kralicek's DF model, QuickTest.

\section{INTRODUCTION}

Corporate governance is organized and based on business processes and procedures in order to protect the rights of shareholders, as well as to influence business decision making which is in the best interest of shareholders. An important segment in corporate governance relates to financial management that implies business analysis, most often based on the analysis of financial indicators that determine business operations results, based on the data from financial statements and market performance of the company. The quality of corporate governance plays an important role in maintaining good business performance indicators.

Companies are exposed to numerous business risks that affect business results, which indirectly reflect on business performance. Austrian Professor Peter Kralicek devised models for identifying business crisis and assessing financial security and performance of a company, named Kralicek's DF indicator and the QuickTest model (Kralicek, 2007).

\section{MODELS FOR IDENTIFYING PETER KRALICEK'S BUSINESS SUCCESS}

In the 1990s, Austrian Professor Peter Kralicek developed his own model, called Kralicek's DF indicator, based on Altman's model for analyzing a sample of companies in the US market. Kralicek's DF indicator was created on a sample of European companies on the markets in Austria, Germany and Switzerland (Mizdraković et al., 2015). Using the data from financial statements, Professor Kralicek conducted a multivariate discriminatory analysis and formed a business success model which is used for predicting bankruptcy (Zenzerović \& Peruško, 2006).

The equation of Kralicek's DF indicator is represented as follows (Alihodžić, 2013):
Correspondence:

Nikica Radović

e-mail:

nradovic@singidunum.ac.rs

$$
\mathrm{DF}=1,5 \mathrm{X} 1+0,08 \mathrm{X} 2+10 \mathrm{X} 3+5 \mathrm{X} 4+0,3 \mathrm{X} 5+0,1 \mathrm{X} 6
$$


$\mathrm{DF}$ is the discriminatory function value; $\mathrm{X} 1$ - net cash flow (EBIT + depreciation) / total liabilities; X2 - total assets / total liabilities; X3 - Profit before interest and taxes / total assets; X4 - Profit before interest and taxes / total revenue; X5 - inventories / total revenue; X6 - operating income / total assets

Kralicek's DF indicator can measure both positive and negative values, where negative values indicate insolvency, while positive values indicate solvency of an analyzed company (Jakovčević \& Andrašić, 2011). Possible values of DF indicators are scaled and presented in Table 1, along with the financial stability estimate.

Table 1. DF value indicator

\begin{tabular}{cc}
\hline DF value indicator & Financial stability \\
\hline$>3,0$ & Excellent \\
\hline$>2,2$ & Very good \\
\hline$>1,5$ & Good \\
\hline$>1,0$ & Medium \\
\hline$>0,3$ & Bad \\
\hline$\leq 0,3$ & The beginning of insolvency \\
\hline$\leq 0,0$ & Moderate insolvency \\
\hline$\leq-1,0$ & Strong insolvency \\
\hline
\end{tabular}

Source: adapted according to Kralicek P.(www.kralicek.at/pdf/qrdruck.pdf)
After developing this indicator, Professor Kralicek created a QuickTest model that is applied in assessing a company's financial performance and the viability of assets. This method offers a quick and accurate assessment of a company's state based on four key indicators (Mussnig et al., 2014). The indicators are grouped so that the first two determine financial stability and the other two determine profitability (Polo \& Caca, 2014).

The indicators of Kralicek's QuickTest are (Alihodžić, 2013):

K1 which shows the share of capital in total sources being calculated as follows: capital / total liabilities;

K2 shows the time of debt repayment i.e. the ratio between total liabilities minus cash and profit after taxation increased by amortization. It is calculated as follows: (total liabilities - cash) / (net profit + depreciation).

K3 shows the viability of total assets in relation to operating profit. It is calculated as follows: EBIT / total assets.

K4 reflects solvency and is calculated as follows: (net profit + depreciation) / operating income.

Considering these four indicators, we obtain values of the grades on a scale of 1 to 5 and assess the state from excellent (grade 1) to insolvency risk (grade 5), which is presented in Table 2. (Kralicek, 2007).

\section{WORK METHODOLOGY}

The aim of this paper is to evaluate business success of hotels in Serbia listed on the Belgrade Stock Exchange using Kralicek's methods for business success estimation.

Table 2. Estimates of Kralicek's Quick Test

\begin{tabular}{|c|c|c|c|c|c|c|}
\hline Indicator & $\begin{array}{l}\text { Excellent } \\
\text { (1) }\end{array}$ & $\begin{array}{l}\text { Good } \\
(2)\end{array}$ & $\begin{array}{l}\text { Medium } \\
\text { (3) }\end{array}$ & $\begin{array}{l}\mathrm{Bad} \\
(4)\end{array}$ & $\begin{array}{c}\text { Insolvency } \\
\text { risk } \\
(5)\end{array}$ & \\
\hline $\begin{array}{l}\text { Self-financing } \\
\text { coefficient (K1) }\end{array}$ & $>30 \%$ & $>20 \%$ & $>10 \%$ & $<10 \%$ & $\begin{array}{l}\text { negative } \\
\text { result }\end{array}$ & \multirow{2}{*}{$\begin{array}{l}\text { FINANCIAL } \\
\text { STABILITY }\end{array}$} \\
\hline $\begin{array}{c}\text { Debt repayment } \\
\text { period in years }(\mathrm{K} 2)\end{array}$ & $<3$ & $<5$ & $<12$ & $<30$ & $>30$ & \\
\hline $\begin{array}{l}\text { Total capital viability } \\
\text { percentage }(\mathrm{K} 3)\end{array}$ & $>15 \%$ & $>12 \%$ & $>8 \%$ & $<8 \%$ & $\begin{array}{l}\text { Negative } \\
\text { result }\end{array}$ & \multirow{2}{*}{ PROFITABILITY } \\
\hline $\begin{array}{l}\text { Cash flow in } \\
\text { business income (K4) }\end{array}$ & $>10 \%$ & $>8 \%$ & $>5 \%$ & $<5 \%$ & $\begin{array}{l}\text { Negative } \\
\text { result }\end{array}$ & \\
\hline
\end{tabular}

Source: adapted according to Kralicek P P.(www.kralicek.at/pdf/qr-druck.pdf)

In accordance with the aforesaid objective, a sample of fifteen hotels, which are issuers of shares on the Belgrade Stock Exchange and which actively operate as categorized accommodation capacities in Serbia, was selected within sector I - Accommodation and food services. It was necessary to use data from the financial statements for 2013, 2014,
2015 and 2016 business years, which were downloaded from the Belgrade Stock Exchange website, i.e. from the profile of each issuer of the shares individually, in order to calculate Kralicek's DF indicators and QuickTest. In this way, a comprehensive database was created and a calculation was made based on which the research results could be observed. 


\section{RESEARCH RESULTS}

The results collected from the calculation of Kralicek's DF indicator based on the data from financial statements for the 2013-2016 period are shown in Table 3.

The obtained results demonstrate that the financial stability of companies varied from year to year. Namely, the level of financial stability was good in 2013. However, it decreased in 2014 but started to rise in 2015 and remained within the framework of good estimates. In 2016 financial stability was evaluated as very good. Medium financial stability in 2014 may have been caused by high liabilities in hotel business, bearing in mind that total liabilities represent a significant aspect of calculating DF indicators for 2014. Lower values reflect fluctuations in the financial stability of hotels, which is most often conditioned by the indebtedness of hotels and low percentage of capacity utilization, therefore leading to small or insufficient amount of income for the liability management in business (Radović \& Stanić, 2016).

Using the data from the financial statements of analyzed hotels, QuickTest indicators were calculated and the obtained values were estimated according to the predetermined criteria given in Table 2. Based on these criteria, values obtained by analyzing the data of the sampled hotels were provided in Table 4.

Table 3. Calculated values of DF indicator for the sample of analyzed hotels

\begin{tabular}{cllll}
\hline DF indicator & 2013. & 2014. & 2015. & 2016. \\
\hline x1 & 0,3726 & 0,1269 & 0,2823 & 5,3730 \\
\hline x2 & 6,6496 & 3,6692 & 5,5098 & 0,0749 \\
\hline x3 & 0,0243 & 0,0162 & 0,0202 & 0,1535 \\
\hline x4 & 0,1121 & 0,0897 & 0,1346 & 0,1832 \\
\hline x5 & 0,0756 & 0,1426 & 0,3594 & 0,3452 \\
\hline x6 & 0,3585 & 0,2995 & 0,3175 & $\mathbf{2 , 6 4 4 2}$ \\
\hline $\begin{array}{c}\text { Financial stability } \\
\text { assessment }\end{array}$ & $\mathbf{1 , 9 5 2 3}$ & $\mathbf{1 , 1 6 7 1}$ & Good & Very good \\
\hline
\end{tabular}

Source: Author's calculation

Table 4. Evaluation of Kralicek's QuickTest for the sample of analyzed hotels

\begin{tabular}{lcccccccc}
\hline \multirow{2}{*}{$\begin{array}{c}\text { QuickTest } \\
\text { indicator }\end{array}$} & \multicolumn{2}{c}{2013.} & \multicolumn{2}{c}{2014.} & & 2015. & 2016. \\
\cline { 2 - 8 } & value & grade & value & grade & value & grade & value & grade \\
\hline Self-financing coefficient (K1) & $52,46 \%$ & 1 & $50,83 \%$ & 1 & $56,99 \%$ & 1 & $56,52 \%$ & 1 \\
\hline Debt repayment period in years (K2) & 21,60 & 4 & 20,37 & 4 & 17,39 & 4 & 9,47 & 3 \\
\hline Total capital viability percentage (K3) & $2,43 \%$ & 4 & $1,62 \%$ & 4 & $2,02 \%$ & 4 & $7,50 \%$ & 4 \\
\hline Cash flow in business period (K4) & $11,79 \%$ & 1 & $12,80 \%$ & 1 & $14,23 \%$ & 1 & $70,90 \%$ & 1 \\
\hline
\end{tabular}

Source: Author's calculation

By examining the obtained results of Kralicek's QuickTest we are able to analyze and evaluate the state of financial possibilities, liquidity, business viability and success of the analyzed sample of hotels. Financial performance analysis of the companies for all four business years ranges from $50.83 \%$ to $56.99 \%$ and is considered excellent. As regards the debt repayment timeline, i.e. company's liquidity, this indicator was estimated as bad for 2013, 2014 and 2015, while in 2016 there were changes and the indicator was in the middle esti- mation phase. It is positive that the trend for debt repayment in a number of years has been steadily declining from 21.6 years to 9.47 years. At the same time, the estimate of total capital viability is in the range of bad values. Therefore, it partially confirms the above assumptions that some indicators obtained in the survey showed poor results as a result of indebtedness of hotels with a small percentage of capacity utilization. Cash flow indicator in business period is excellent according to the ratings, which is in correlation with the 
hotel business specificity which involves a large amount of cash derived from regular business activities such as maintaining accommodation services, offering food and additional services that hotels provide in their regular business processes. This indicates that the available funds are not being used in an optimal way to reduce indebtedness and raise the company's viability.

\section{CONCLUSION}

The obtained research results of Kralicek's DF indicators and values for QuickTest illustrate that the value of equity capital and cash flow are considered excellent, while the financial stability of analyzed hotels is satisfactory, with substantial business liabilities. We can conclude that long repayment periods and low viability are directly related to low percentage of capacity utilization and long-term indebtedness, which is specific to the current situation in the hotel business in Serbia. Namely, after the privatization of analyzed hotels, new management of certain hotels decided to take loans for the purpose of reconstructing facilities in order to modernize the equipment for providing services as well as to raise the level of services. Furthermore, investments are important in order to categorize and maintain facilities, "revive" and improve business of older hotels in the accommodation sector in Serbia.

\section{LITERATURE}

Alihodžić, A. (2013). Testiranje primene Kraličekovog DF pokazatelja na Beogradskoj berzi, Bankarstvo No. 3, p. 82.

Jakovčević, K. \& Andrašić, J. (2011). Indikatori poteškoća u funkcionisanju industrijskog preduzeća, Industrija 3/2011, p.178.

Kralicek, P. (2007). Ertrags und Vermogensanalyse (QuickTest), p.4, retrieved August 29, 2017, from www.kralicek.at/pdf/ qr-druck.pdf

Mizdraković, V., Knežević, G. \& Stanić, N. (2015). Bankruptcy risk exposure of Serbian hotels in the period 2008-2012, SITCON 2015-Singidunum International Tourism Conference, Conference proceedings, p. 165.

Mussnig, W., Bleyer, M., Giermaier, G. \& Rausch A. (2014). Controlling für Führungskräfte Analysieren, Linde, p.263.

Polo, A. \& Caca, E. (2014). Kralicek QuickTest - An Analysis Tool for Economics Units Determination in Liability Difficulty, European Scientific Journal, Vol 10, No. 19. p. 148.

Radović, N. \& Stanić, N. (2016). Analiza pokazatelja rentabilnosti u poslovanju hotelskih preduzeća, FINIZ 2016, p.172.

Zenzerović, R. \& Peruško, T. (2006). Kratki osvrt na modele za predviđanja stečaja, Ekonomska istraživanja Vol 19/No. 2, p. 132-151.

http://www.belex.rs/trzista_i_hartije/sektori/I, retrieved August 29, 2017 